\title{
Faktor Risiko yang Mempengaruhi Manajemen Glukosa pada Pasien Diabetes Mellitus di Makassar, Sulawesi Selatan, Indonesia
}

\author{
Amriati Mutmainna ${ }^{1 *}$ \\ ${ }^{1}$ STIKES Nani Hasanuddin Makassar, Jl. Perintis Kemerdekaan VIII, No. 24, Kota Makassar, Indonesia, 90245 \\ *e-mail: amriatimutmainna29@gmail.com
}

(Received: 18-03-2019; Reviewed: 25-03-2019; Accepted: 12-04-2019)

\begin{abstract}
Diabetes is a serious lifetime health condition that occurs when blood glucose amount is too high. The study purpose was the effect of age, glucose levels, BMI, gender, and smoking history that could influence the glucose management assessment in diabetes mellitus patients. The research design used was a descriptive survey with a cross-sectional approach. Seventy-two (72) respondents were taken as subjects in this study. Frequency, percentage, mean, and chisquare are used to find out quantitative data. Rating for glucose management ranges from "very high levels" to "low levels". The majority of participants in 2 hospitals found more than 45 years, female participants, had high blood sugar, had a normal weight, and not smokers. In addition, there was no significant difference in glucose management according to age ( $p$-value=0.319), gender ( $p$-value $=0.497)$, BMI ( $p$-value=0.175) and smoking history ( $p$ value $=0.940$ ). But then, there were significant differences in participants' glucose management when grouped based on blood sugar levels $(p$-value $=0,000)$. This study concluded that poor glucose management was obtained from the respondents. This glucose management assessment is considered an effective approach to overcome various conditions in diabetes mellitus patients. In other words, researcher contributes to the patients interests with diabetes mellitus considering the ability to control blood sugar for diabetes mellitus patients is an important role in having a healthy lifestyle.
\end{abstract}

Keywords : age, blood sugar levels, BMI, gender, glucose management, history of smoking.

\begin{abstract}
Abstrak
Diabetes adalah kondisi kesehatan serius seumur hidup ketika tingginya jumlah glukosa darah. Tujuan penelitian adalah pengaruh usia, kadar glukosa, IMT, jenis kelamin, dan riwayat merokok yang dapat mempengaruhi penilaian manajemen glukosa pasien diabetes mellitus. Desain penelitian adalah survei deskriptif dengan pendekatan cross sectional. Tujuh puluh dua (72) responden diambil sebagai subyek dalam penelitian. Frekuensi, persentase, nilai mean, dan chi-square digunakan untuk mengetahui data kuantitatif. Rating penilaian untuk manajemen glukosa berkisar dari "tingkat sangat tinggi" hingga "tingkat rendah". Mayoritas peserta di 2 rumah sakit ditemukan lebih dari 45 tahun, peserta perempuan, memiliki gula darah tinggi, memiliki berat badan normal, dan bukan perokok. Selain itu, tidak ada perbedaan signifikan dari manajemen glukosa menurut usia (nilai $\mathrm{p}=0,319$ ), jenis kelamin (nilai $\mathrm{p}=0,497$ ), IMT (nilai $\mathrm{p}=0,175$ ) dan riwayat merokok (nilai $\mathrm{p}=0,940$ ). Namun, ada perbedaan signifikan pada manajemen glukosa peserta saat dikelompokkan berdasarkan kadar gula darah (nilai $\mathrm{p}=0,000$ ). Penelitian ini menyimpulkan bahwa manajemen glukosa buruk yang didapatkan dari responden. Penilaian manajemen glukosa ini dianggap sebagai pendekatan yang efektif untuk mengatasi berbagai kondisi pasien diabetes mellitus. Selain itu, peneliti berkontribusi untuk kepentingan pasien diabetes mellitus untuk mengontrol gula darah pasien diabetes mellitus yang berperan penting dalam memiliki gaya hidup sehat.
\end{abstract}

Kata Kunci : Usia, Kadar Gula Darah, IMT, Jenis Kelamin, Manajemen Glukosa, Riwayat Merokok 


\section{Pendahuluan}

Perkiraan global terbaru dari Federasi Diabetes Internasional memperkirakan bahwa pada tahun 2040, 642 juta orang akan hidup dengan diabetes (The Lancet, 2017). Organisasi Kesehatan Dunia (2017) menyatakan bahwa jumlah penderita diabetes telah meningkat dari 108 juta pada tahun 1980 menjadi 422 juta pada tahun 2014. Prevalensi global diabetes di kalangan orang dewasa di atas 18 tahun telah meningkat dari 4,7\% pada tahun 1980 menjadi 8,5\% di 2014 .

Data kesehatan provinsi Sulawesi Selatan menunjukkan bahwa pasien dengan diabetes mellitus yang diobati di klinik kesehatan masyarakat pada tahun 2010 adalah 9,61\%, 2011 adalah 9,32\%, meningkat pada 2012 sebesar $12,6 \%$. Data dinas kesehatan Kota Makassar mengungkapkan bahwa pasien diabetes mellitus pada tahun 2012 sebanyak 14.067 kasus, meningkat 14.604 kasus pada tahun 2013, dan pada tahun 2014 meningkat sebanyak 21.452 kasus (Syatriani, 2017).

Namun, salah satu faktor kegagalan pengobatan adalah ketidakpatuhan terhadap terapi yang direncanakan, salah satu upaya terpenting untuk meningkatkan kepatuhan pasien terhadap terapi adalah dengan memberikan konseling yang komprehensif, akurat, dan terstruktur tentang terapi. Pengadaan penelitian ini sangat penting karena diabetes adalah penyakit yang berhubungan dengan gaya hidup pasien. Oleh karena itu, tujuan dari penelitian ini adalah penilaian manajemen glukosa pasien dengan diagnosis diabetes mellitus.

\section{Metode}

Dalam studi ini, peneliti menggunakan studi survei deskriptif yang menggambarkan manajemen glukosa pasien yang didiagnosis dengan diabetes mellitus. Para peserta penelitian adalah mereka yang termasuk dalam kriteria inklusi di mana ada 72 peserta. Kriteria inklusi atau kriteria yang ditetapkan oleh peneliti yang berpartisipasi dalam studi penelitian ini yaitu sebagai berikut:

1. Dirawat inap di Rumah Sakit Umum Daerah (RSUD) Labuang Baji Makassar dan Rumah Sakit Tingkat II Pelamonia Makassar.

2. Peserta penelitian berusia di atas 18 tahun.

3. Pesertapenelitian bersedia berpartisipasi dalam penelitian.

4. Peserta penelitian didiagnosis diabetes mellitus tipe 1 maupun tipe 2 .

5. Peserta penelitian memiliki informasi terbatas tentang kontrol gula darah.

6. Peserta penelitian cenderung bekerja sama dan bersedia mengisi instrumen yang disediakan oleh peneliti.

7. Peserta penelitian yang enggan berpartisipasi dalam penelitian ini dikecualikan sebagai peserta.

Dengan kata lain, data dikumpulkan dari pasien diabetes Labuang Baji dan Rumah Sakit Pelamonia Makassar, Sulawesi Selatan, Indonesia. Selanjutnya, penelitian ini mencakup total populasi pasien diabetes yang dirawat di rumah sakit di 2 rumah sakit ini dan yang berusia 18 - 60 tahun. Selain itu, periode pengumpulan data untuk penelitian ini adalah untuk durasi dua bulan dari 12 Februari - 12 April 2018. Dan kemudian, peserta yang didiagnosis diabetes mellitus tipe 1 atau tipe 2 dilibatkan dalam penelitian ini.

Data primer dalam penelitian ini adalah profil peserta dalam hal usia, jenis kelamin, kadar gula darah, indeks massa tubuh, dan riwayat merokok. Selain itu, pertanyaan untuk pasien diabetes mellitus menggunakan Diabetes SelfManagement Questionnaire (DSMQ) oleh Schmitt et al. (2013) untuk menilai glukosa manajemen para peserta. Selanjutnya, data utama kadar gula darah adalah dari menggunakan meteran glukosa darah ACCU. Peneliti menggunakan tes glukosa plasma acak yang berarti bahwa jika peserta yang memiliki $200 \mathrm{mg} / \mathrm{dl}$ dianggap memiliki kadar gula darah yang tinggi. Selain itu, untuk data primer indeks massa tubuh, skala platform di rumah sakit digunakan untuk mengetahui berat dan tinggi peserta. Setelah itu, peneliti mengelompokkan indeks massa tubuh di bawah empat kategori: kurus, berat badan normal, kelebihan berat badan, dan obesitas yang menurut American Cancer Society (2016).

Selain itu, peneliti menggunakan DSMQ oleh untuk menilai glukosa manajemen para peserta. Skala peringkat dirancang sebagai skala Likert empat poin dengan opsi tanggapan "berlaku untuk saya sangat banyak" (tiga poin), 'berlaku untuk saya sampai tingkat tertentu' (dua poin), 'berlaku untuk saya untuk beberapa derajat' (satu poin), dan 'tidak berlaku untuk saya' (nol poin). Item dan skala karakteristik DSMQ serta validitas faktorial dan konvergen dianalisis, dan konvergensi dengan HbA1c dibandingkan dengan SDSCA.

Sehingga, kesimpulan memberikan bukti awal bahwa DSMQ adalah instrumen yang dapat diandalkan dan valid dan memungkinkan penilaian yang efisien dari perilaku perawatan diri yang terkait dengan kontrol glikemik. Kuesioner harus berharga untuk analisis ilmiah serta penggunaan klinis pada pasien diabetes tipe 1 dan tipe 2.

Lebih lanjut, Fatimah (2016) menegaskan bahwa DSMQ dalam bahasa Indonesia sudah valid dan dapat diandalkan. Uji validitas dan reliabilitas dilakukan pengambilan data dari 30 peserta yang merupakan penderita diabetes mellitus di Posbindu Wilayah Kerja Puskesmas Pisangan. Hasil uji validitas DSMQ adalah sebagai berikut: hasil uji validitas dan reliabilitas dengan derajat kebebasan 30-2 = 28 ( $\mathrm{r}$ tabel 0,312), dalam angket manajemen diri ada 7 item pernyataan tidak valid yaitu $3,4,5,8,9,13$, dan 14 , tetapi pernyataan pada nomor yang tidak valid adalah penting dalam manajemen diri diabetes, maka pernyataan itu dibuang tetapi struktur kata itu tetap. Sedangkan hasil uji 
reliabilitas kuesioner adalah alpha cronbach's r 0.635 sehingga kuesioner dinyatakan reliabel. Selanjutnya, instrumen manajemen diri yang telah diperbaiki digunakan untuk pengambilan data. Total skor responden terendah adalah 0 dan tertinggi adalah 48 .

Akhirnya, berdasarkan uji validitas dan reliabilitas yang dilakukan di luar negeri oleh Schmitt et al. (2013) dan di Indonesia oleh Fatimah (2016) sudah dinyatakan valid dan reliabel untuk dimanfaatkan dalam penelitian ini. Ada empat komponen dalam DSMQ, tetapi peneliti hanya menggunakan satu yang merupakan manajemen glukosa.

\section{Hasil}

Ringkasan hasil pada penelitian ini dirinci di bawah ini yaitu sebagai berikut:

1. Profil Partisipan

Mayoritas usia peserta di 2 rumah sakit ditemukan lebih dari 45 tahun dengan 44 atau 61,1\%. Sementara itu, usia kurang dari atau sama dengan 45 tahun adalah 28 peserta dengan persentase 38,9\%. Ini menunjukkan bahwa mayoritas pasien diabetes mellitus adalah orang dewasa yang lebih tua. Selanjutnya, hasil penelitian bahwa mayoritas 47 atau 65,3\% dari peserta di 2 rumah sakit adalah perempuan. Dengan demikian menyiratkan bahwa mayoritas pasien DM adalah perempuan. Dan juga, mayoritas 53 atau 73,6\% dari peserta memiliki kadar gula darah yang lebih dari $200 \mathrm{mg} / \mathrm{dl}$. Ini berarti diabetes mellitus memiliki kadar gula darah yang tinggi. Ini menyiratkan bahwa mayoritas dari mereka adalah pasien diabetes, melalui implikasinya terhadap obat atau intervensi, kadar gula darah mereka yang biasa tinggi ketika dikurangi ke tingkat normal.

Selain itu pula, jumlah tertinggi peserta 29 atau 40,3\% dari peserta memiliki BMI normal, 40 atau 55,6\% di atas tingkat normal seperti yang ditunjukkan oleh data spesifik di mana peserta yang 19 atau 26,4\% dianggap kelebihan berat badan, dan 21 atau 29,2\% mengalami obesitas. Selanjutnya, mayoritas, 53 atau 73,6\% dari peserta adalah bukan perokok dan 9 atau 26,4\% adalah perokok. Hasilnya menunjukkan bahwa merokok untuk sebagian besar peserta bukan sebagai faktor risiko untuk menjadi pasien diabetes. Hal ini ditunjukkan pada tabel 1 yang dimana jumlah keseluruhan responden yaitu $72(n=72)$, yaitu sebagai berikut:

\section{Tabel 1. Profil partisipan}

\begin{tabular}{llcc}
\hline & \multicolumn{1}{c}{ Variable } & Frekuensi & Persentase (\%) \\
\hline \multirow{2}{*}{ Usia } & Kurang dari sama dengan 45 tahun & 28 & 34.7 \\
& Lebih dari 45 tahun & 44 & 65.3 \\
\hline \multirow{2}{*}{ Jenis Kelamin } & Laki-laki & 25 & 38.9 \\
& Perempuan & 47 & 61.1 \\
\hline \multirow{2}{*}{ Kadar Gula } & Kurang dari 200 mg/dl & 19 & 26.4 \\
Darah & Lebih dari sama dengan 200 mg/dl & 53 & 73.6 \\
\hline \multirow{2}{*}{ IMT } & Kurang dari 18.5 & 3 & 4.2 \\
& $18.5-24.9$ & 29 & 40.3 \\
& $25-29.9$ & 19 & 26.4 \\
Riwayat & 30 or more & 21 & 29.2 \\
Merokok & Ada & 19 & 26.4 \\
\hline
\end{tabular}

2. Perbedaan signifikan dalam manajemen glukosa peserta partisipan saat dikelompokkan sesuai dengan variabel profil partisipan:

a. Seperti yang ditunjukkan oleh nilai p-value 0,319, tingkat manajemen glukosa peserta tidak berbeda secara signifikan ketika mereka dikelompokkan berdasarkan usia. Hal ini ditunjukkan pada tabel 2, yaitu sebagai berikut:

Tabel 2. Signifikan dalam manajemen glukosa peserta partisipan saat dikelompokkan sesuai dengan usia

\begin{tabular}{|c|c|c|c|c|c|c|c|}
\hline & \multirow{2}{*}{ Variabel } & \multicolumn{4}{|c|}{ Manajemen Glukosa } & \multirow{2}{*}{ Total } & \multirow{2}{*}{$\propto=0.05$} \\
\hline & & Sesuai & Cukup sesuai & Kurang sesuai & Tidak sesuai & & \\
\hline \multirow{3}{*}{ Usia } & $\leq 45$ tahun & 2 & 3 & 5 & 18 & 28 & \multirow{5}{*}{$\begin{array}{c}\mathrm{H} 0 \\
\text { Diterima }\end{array}$} \\
\hline & $>45$ tahun & 10 & 6 & 7 & 21 & 44 & \\
\hline & Total & 12 & 9 & 12 & 39 & 72 & \\
\hline \multicolumn{7}{|c|}{ Nilai $X^{2}=3.515$} & \\
\hline \multicolumn{7}{|c|}{ Nilai $\rho=0.319$} & \\
\hline
\end{tabular}


b. Tidak ada perbedaan signifikan dari manajemen glukosa pada pria dan wanita. Ini disesuaikan dengan nilai X2 2,380 dan p-value 0,497. Hal ini ditunjukkan pada tabel 3, yaitu sebagai berikut:

Tabel 3. Signifikan dalam manajemen glukosa peserta partisipan saat dikelompokkan sesuai dengan jenis kelamin

\begin{tabular}{|c|c|c|c|c|c|c|}
\hline \multirow[b]{2}{*}{ Variabel } & \multicolumn{4}{|c|}{ Manajemen Glukosa } & \multirow[b]{2}{*}{ Total } & \multirow[b]{2}{*}{$\propto=0.05$} \\
\hline & Sesuai & $\begin{array}{l}\text { Cukup } \\
\text { sesuai }\end{array}$ & Kurang sesuai & Tidak sesuai & & \\
\hline Laki-laki & 5 & 2 & 6 & 12 & 25 & \multirow{5}{*}{$\begin{array}{c}\mathrm{H} 0 \\
\text { Diterima }\end{array}$} \\
\hline Kelamin Perempuan & 7 & 7 & 6 & 27 & 47 & \\
\hline Total & 12 & 9 & 12 & 39 & 72 & \\
\hline \multicolumn{6}{|c|}{ Nilai $X^{2}=2.380$} & \\
\hline & & Nilai $\rho=$ & & & & \\
\hline
\end{tabular}

c. Nilai probabilitas 0,000 menunjukkan mengungkapkan bahwa ada perbedaan yang signifikan pada manajemen glukosa peserta saat dikelompokkan sesuai dengan kadar gula darah. Seperti ditunjukkan pada tabel, proporsi tertinggi dari peserta dengan tingkat manajemen glukosa sedang sampai rendah adalah mereka dengan kadar gula tinggi (200 mg / dl atau lebih). Sebaliknya, mereka yang memiliki kadar gula rendah memiliki tingkat manajemen glukosa tinggi hingga sangat tinggi. Hal ini ditunjukkan pada tabel 4, yaitu sebagai berikut:

Tabel 4. Signifikan dalam manajemen glukosa peserta partisipan saat dikelompokkan sesuai dengan kadar gula darah

\begin{tabular}{|c|c|c|c|c|c|c|c|}
\hline & \multirow[b]{2}{*}{ Variabel } & \multicolumn{4}{|c|}{ Manajemen Glukosa } & \multirow[b]{2}{*}{ Total } & \multirow[b]{2}{*}{$\propto=0.05$} \\
\hline & & Sesuai & $\begin{array}{l}\text { Cukup } \\
\text { sesuai }\end{array}$ & $\begin{array}{c}\text { Kurang } \\
\text { sesuai }\end{array}$ & $\begin{array}{l}\text { Tidak } \\
\text { sesuai }\end{array}$ & & \\
\hline \multirow{3}{*}{$\begin{array}{l}\text { Kadar } \\
\text { gula } \\
\text { darah }\end{array}$} & $\begin{array}{l}\text { Dibawah } 200 \\
\mathrm{mg} / \mathrm{dl}\end{array}$ & 11 & 7 & 0 & 1 & 19 & \multirow{4}{*}{$\begin{array}{c}\text { H0 } \\
\text { Ditolak }\end{array}$} \\
\hline & $\begin{array}{l}\text { Diatas } \\
\text { dengan } 200 \mathrm{mg} / \mathrm{dl}\end{array}$ & 1 & 2 & 12 & 38 & 53 & \\
\hline & Total & 12 & 9 & 12 & 39 & 72 & \\
\hline \multicolumn{7}{|c|}{ Nilai $X^{2}=54.257$} & \\
\hline
\end{tabular}

d. Studi ini menunjukkan bahwa tidak ada perbedaan yang signifikan dalam manajemen glukosa peserta saat dikelompokkan berdasarkan indeks massa tubuh dengan nilai p-value 0,175 dan nilai X2 12,744. Ini menunjukkan peserta indeks massa tubuh yang gemuk memiliki manajemen glukosa yang sama dengan kelebihan berat badan, berat badan normal, dan berat badan kurang. Hal ini ditunjukkan pada tabel 5, yaitu sebagai berikut:

Tabel 5. Signifikan dalam manajemen glukosa peserta partisipan saat dikelompokkan sesuai dengan indeks massa tubuh

\begin{tabular}{|c|c|c|c|c|c|c|c|}
\hline \multirow{2}{*}{\multicolumn{2}{|c|}{ Variabel }} & \multicolumn{4}{|c|}{ Manajemen Glukosa } & \multirow{2}{*}{ Total } & \multirow{2}{*}{$\alpha=0.05$} \\
\hline & & Sesuai & Cukup sesuai & Kurang sesuai & Tidak sesuai & & \\
\hline \multirow{5}{*}{$\begin{array}{l}\text { Indeks } \\
\text { Massa } \\
\text { Tubuh }\end{array}$} & Kurus & 0 & 1 & 1 & 1 & 3 & \multirow{7}{*}{$\begin{array}{c}\mathrm{H} 0 \\
\text { Diterima }\end{array}$} \\
\hline & Normal & 8 & 6 & 4 & 11 & 29 & \\
\hline & $\begin{array}{l}\text { Berat } \\
\text { badan } \\
\text { berlebih }\end{array}$ & 2 & 2 & 3 & 12 & 19 & \\
\hline & Obesitas & 2 & 0 & 4 & 15 & 21 & \\
\hline & tal & 12 & 9 & 12 & 39 & 72 & \\
\hline \multicolumn{7}{|c|}{ Nilai $X^{2}=12.744$} & \\
\hline & & & Nilai $\rho=0$ & & & & \\
\hline
\end{tabular}

e. Studi ini menunjukkan tidak ada perbedaan yang signifikan dalam manajemen glukosa dari para peserta ketika dikelompokkan berdasarkan riwayat merokok dengan p-value 0,940 melalui Uji Chi-Square. Ini menjelaskan 
bahwa perokok dan non-perokok memiliki tingkat manajemen glukosa yang sama. Hal ini ditunjukkan pada tabel 6, yaitu sebagai berikut:

\section{Tabel 6. Signifikan dalam manajemen glukosa peserta partisipan saat dikelompokkan sesuai dengan indeks massa tubuh}

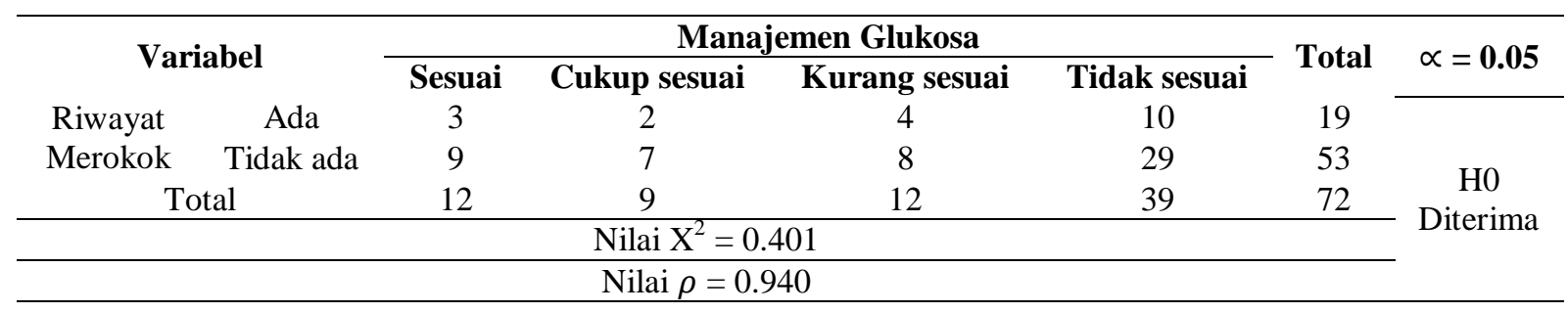

\section{Pembahasan}

Profil partisipan yang didapatkan dalam penelitian ini adalah salah satunya yaitu mengenai usia. Mayoritas usia peserta di 2 rumah sakit ditemukan lebih dari 45 tahun dengan 44 atau 61,1\%. Sementara itu, usia kurang dari atau sama dengan 45 tahun adalah 28 peserta dengan persentase 38,9\%. Ini menunjukkan bahwa mayoritas pasien diabetes mellitus adalah orang dewasa yang lebih tua. Secara konseptual, pasien DM mengalami jumlah kasus terbanyak terjadi pada rentang usia lansia berdasarkan kelompok usia berdasarkan Kementerian Kesehatan Republik Indonesia (2009) mulai dari 46 tahun hingga 55 tahun sebanyak 22 orang responden (50\%) (Depkes RI, 2009). Data ini konsisten dengan pernyataan dari American Diabetes Association (ADA), bahwa usia di atas 45 tahun adalah salah satu faktor risiko untuk diabetes tipe 2 (ADA, 2008). Selain itu, menurut Perkeni (2006) risiko terkena diabetes mellitus tipe 2 meningkat dengan bertambahnya usia. Selain itu, sejumlah perubahan akan terjadi seiring bertambahnya usia, termasuk anatomi, fisiologi, psikologi, dan sosiologi. Califano menyarankan bahwa usia adalah salah satu faktor risiko untuk masalah kesehatan seperti penyakit DM. Insidensi penyakit DM meningkat dengan bertambahnya usia.

Selain faktor usia, peneliti juga meneliti dari segi jenis kelaminnya. Hasil penelitian bahwa mayoritas 47 atau $65,3 \%$ dari peserta di 2 rumah sakit adalah perempuan. Dengan demikian menyiratkan bahwa mayoritas pasien DM adalah perempuan. Secara konseptual, hasil penelitian yang dilakukan oleh Rumah Sakit Koja menyatakan bahwa prevalensi diabetes mellitus tipe 2 yang terjadi pada wanita adalah 62\%, lebih besar daripada prevalensi pada pria (Santoso et al., 2004). Hal ini sejalan dengan penelitian yang disampaikan oleh Azrul Azwar yang menyatakan bahwa ada variasi dalam prevalensi tipe 2. diabetes mellitus antara pria dan wanita di beberapa daerah (Azwar, 1985). Lebih lanjut, Sucipto \& Rosa (2014) menyatakan bahwa peserta terdiri dari 59,1\% jenis kelamin perempuan dan 40,9\% jenis kelamin laki-laki.

Selanjutnya, hasil yang didapatkan pula dalam penelitian ini bahwa mayoritas 53 atau 73,6\% dari peserta memiliki kadar gula darah yang lebih dari $200 \mathrm{mg} / \mathrm{dl}$. Ini berarti diabetes mellitus memiliki kadar gula darah yang tinggi. Ini menyiratkan bahwa mayoritas dari mereka adalah pasien diabetes, melalui implikasinya terhadap obat atau intervensi, kadar gula darah mereka yang biasa tinggi ketika dikurangi ke tingkat normal. Selain itu, diabetes mellitus adalah istilah deskriptif untuk keluarga gangguan yang ditandai dengan intoleransi karbohidrat kronis (puasa dan / atau hiperglikemia pasca-prandinal) dan pengembangan komplikasi medis jangka panjang (Winter \& Signorino, 2002).

Selain itu pula, jumlah tertinggi peserta 29 atau 40,3\% dari peserta memiliki BMI normal, 40 atau 55,6\% di atas tingkat normal seperti yang ditunjukkan oleh data spesifik di mana peserta yang 19 atau 26,4\% dianggap kelebihan berat badan, dan 21 atau 29,2\% mengalami obesitas. Hal ini sejalan dengan teori Magee (2004) yang menyatakan diabetes tipe 2 adalah gangguan metabolisme yang disebabkan oleh ketidakmampuan tubuh untuk menggunakan insulin secara tepat. Gangguan ini terjadi ketika tubuh dihasilkan dari banyak insulin, tetapi insulin tidak dapat melakukan tugasnya. Fungsi pankreas adalah menghasilkan lebih banyak insulin. Sementara glukosa darah meningkat yang membuatnya lebih tersedia untuk pasien diabetes mellitus dengan obesitas. Selain itu, aktivitas pankreas berusaha lebih keras dalam jangka waktu lama. Dengan demikian, sel-sel tubuh menjadi kebal terhadap insulin. Ini berarti, pasien diabetes mellitus yang sebelum obesitas akan mengalami gangguan metabolisme sehingga menyebabkan pasien diabetes mellitus berkurang menjadi berat badan normal atau kurang berat badan.

Dan juga, mayoritas 53 atau 73,6\% dari peserta adalah bukan perokok dan 9 atau 26,4\% adalah perokok. Hasilnya menunjukkan bahwa merokok untuk sebagian besar peserta bukan sebagai faktor risiko untuk menjadi pasien diabetes. Selain itu, menurut Patja et al. (2005) hubungan merokok dengan risiko diabetes tipe 2 dimodifikasi oleh obesitas dan aktivitas fisik. Merokok memiliki hubungan bertingkat dengan diabetes tipe 2 risiko, dan tetap signifikan setelah mengendalikan usia dan faktor risiko utama. Merokok meningkatkan risiko diabetes tipe 2 di semua level BMI dan aktivitas fisik. 
Perbedaan signifikan dalam manajemen glukosa peserta partisipan saat dikelompokkan sesuai dengan variabel profil partisipan. Seperti yang ditunjukkan oleh nilai p-probabilitas 0,319 , tingkat manajemen glukosa peserta tidak berbeda secara signifikan ketika mereka dikelompokkan berdasarkan usia. Ini berarti bahwa semua peserta, tanpa memandang usia menunjukkan tingkat manajemen glukosa yang sama. Ini sejalan dengan Mooradian et al. (1999) yang menyatakan strategi manajemen untuk diabetes pada orang dewasa yang lebih tua tidak berbeda dengan diabetes pada kelompok yang lebih muda. Selain itu pula, tidak ada perbedaan signifikan dari manajemen glukosa pada pria dan wanita. Ini disesuaikan dengan nilai X2 2,380 dan p-value 0,497. Ini berarti bahwa pria dan wanita terwujud tingkat manajemen glukosa yang sama. Penelitian ini sejalan dengan penelitian yang dilakukan oleh Fatimah (2016) yang menyatakan bahwa analisis gender dengan manajemen glukosa menunjukkan tidak ada hubungan yang signifikan antara gender dan manajemen glukosa.

Selanjutnya, nilai probabilitas 0,000 menunjukkan mengungkapkan bahwa ada perbedaan yang signifikan pada manajemen glukosa peserta saat dikelompokkan sesuai dengan kadar gula darah. Seperti ditunjukkan pada tabel, proporsi tertinggi dari peserta dengan tingkat manajemen glukosa sedang sampai rendah adalah mereka dengan kadar gula tinggi (200 mg / dl atau lebih). Sebaliknya, mereka yang memiliki kadar gula rendah memiliki tingkat manajemen glukosa tinggi hingga sangat tinggi. Ini sejalan dengan Schmitt et al. (2013) menyatakan pasien dengan kontrol glikemik yang baik melaporkan secara signifikan lebih banyak manajemen glukosa. Dan juga, studi ini menunjukkan bahwa tidak ada perbedaan yang signifikan dalam manajemen glukosa peserta saat dikelompokkan berdasarkan indeks massa tubuh dengan nilai p-value 0,175 dan nilai X2 12,744. Ini menunjukkan peserta indeks massa tubuh yang gemuk memiliki manajemen glukosa yang sama dengan kelebihan berat badan, berat badan normal, dan berat badan kurang. Ini sejalan dengan teori Mooradian et al. (1999) yang menuntut yang sering kelebihan berat badan, obesitas tidak umum di antara pasien diabetes.

Selain itu, studi ini menunjukkan tidak ada perbedaan yang signifikan dalam manajemen glukosa dari para peserta ketika dikelompokkan berdasarkan riwayat merokok dengan p-value 0,940 melalui Uji Chi-Square. Ini menjelaskan bahwa perokok dan non-perokok memiliki tingkat manajemen glukosa yang sama. Selain itu, teori Chang (2012) menuntut merokok meningkatkan risiko terkena diabetes, dan memperburuk komplikasi mikro dan makrovaskular diabetes mellitus. Merokok dikaitkan dengan resistensi insulin, peradangan dan dislipidemia, tetapi mekanisme yang tepat di mana merokok mempengaruhi diabetes mellitus tidak jelas. Namun, berhenti merokok adalah salah satu target penting untuk mengendalikan diabetes dan mencegah komplikasi diabetes.

\section{Kesimpulan}

Studi ini menyimpulkan bahwa pada umumnya ada pengaruh manajemen glukosa pada pasien dengan diagnosa medis diabetes mellitus berdasarkan kadar gula darah. Selanjutnya, penderita diabetes mellitus mengalami jumlah kasus paling tinggi terjadi di penelitian ini pada usia di atas 45 tahun, peserta berjenis kelamin perempuan, memiliki kadar gula darah tinggi, IMT normal, dan tidak ada riwayat merokok. Selain itu pula, manajemen glukosa dari para peserta dalam penelitian ini menunjukkan bahwa hal tersebut dipengaruhi oleh kadar gula darah partisipan. Sebaliknya, pada usia, jenis kelamin, indeks massa tubuh dan riwayat merokok yang tidak memiliki pengaruh untuk manajemen glukosa. Manajemen glukosa adalah hal penting yang harus dilakukan untuk pasien diabetes mellitus karena dapat membantu pasien untuk mengontrol gula darah dalam kisaran normal.

\section{Referensi}

American Diabetes Association (ADA). (2008). Nutrition Recommendations and Inervention for Diabete. Diabetes Care, 31 (Suppl. 1): 61-78. Retrieved from http://www.care.diabetesjournals.org

American Cancer Society. (2016). Normal Weight Ranges: Body Mass Index (BMI). Retrieved from https://www.cancer.org/cancer/cancer-causes/diet-physical-activity/body-weight-and-cancer-risk/adult-bmi.html

Azwar, A. (1985). Epidemiologi Hipertensi. Bagian Ilmu Kedokteran Komunitas Fakultas Kedokteran Universitas Indonesia, Jakarta.

Chang, S. A. (2012). Smoking and Type 2 Diabetes Mellitus. Diabetes \& Metabolism Journal; 36(6): 399-403. doi: $\underline{10.4093 / \mathrm{dmj} .2012 .36 .6 .399}$

Departemen Kesehatan Republik Indonesia (Depkes RI). (2008). Pedoman Pengendalian Diabetes Mellitus dan Penyakit Metabolik. Jakarta. 
Fatimah. (2016). Hubungan faktor personal dan dukungan keluarga dengan manajemen diri penderita diabetes mellitus di posbindu wilayah kerja puskesmas pisangan kota Tangerang Selatan tahun 2016. Jakarta: Universitas Islam Negeri Syarif Hidayatullah.

Magee, E. (2004). Tell me what to eat if I have diabetes, Hidup lebih baik bersama diabetes: Dilengkapi metode diet \& Informasi Nutrisi. Jakarta: PT Bhuana Ilmu Populer Kelompok Gramedia.

Mooradian, A. D., McLaughlin, S., Boyer, C. C., and Winter, J. (1999). Diabetes Care for Older Adults. Diabetes Spectrum: Volume 12, Number 2, pp 70-77. Retrieved from http://journal.diabetes.org/diabetesspectrum/99v12n2/pg70.htm

Patja, K., Jousilahti, P., Hu, G., Valle, T., Qiao, Q., Tuomilehto, J. (2005). Effects of smoking, obesity and physical activity on the risk of type 2 diabetes in middle-aged Finnish men and women. Journal of Internal Medicine; 258(4):356-362. doi: 10.1111/j.1365-2796. 2005.01545.x

Santoso M, Lian S, Yudy. (2004). Gambaran Pola Penyakit Diabetes Melitus di Bagian Rawat Inap RSUD Koja 2000 2004. Jakarta.

Schmitt, A., Gahr, A., Hermaanns, N., Kulzer, B., Huber, J., and Haak, T. (2013). The Diabetes Self-Management Questionnaire (DSMQ): Development and evaluation of an instrument to assess diabetes self-care activities associated with glycaemic control. Health and Quality of Life Outcomes; 11:138. Retrieved from http://doi.org/10.1186/1477-7525-11-138

Sucipto, A. and Rosa, E. M. (2014). Efektifitas konseling diabetes mellitus dalam meningkatkan kepatuhan dan pengendalian gula darah pada diabetes mellitus tipe 2. Muhammadiyah Journal Nursing. Retrieved from journal.umy.ac.id/index.php/ijnp/article/download/637/796

Syatriani, S. (2017).Tingkatkankualitashiduppenderita DM tipe 2 melaluikeluarga. Retrieved from http://rakyat sulsel.com/tingkatkan-kualitas-hidup-penderita-dm-tipe-2-melalui-keluarga.html

The Lancet. (2017). Obesity and diabetes in 2017: A new year. The Lancet; Vol.389, No.10064.doi: http://dx.doi.org/10. 1016/S0140-6736(17)30004-1

Winter, W. E. and Signorino, M. R. (2002). Diabetes mellitus: Pathophysiology, etiologies, complications, management, and laboratory evaluation. Washington, DC: AACC Press

World Health Organization (WHO). (2017). Diabetes. Retrieved from http://www.who.int/mediacentre/fact sheets/fs312/en/ 